\title{
KARAKTERISTIK AKTA RISALAH LELANG SEBAGAI AKTA OTENTIK
}

\author{
Mohamad Erik ${ }^{1}$ \\ Program Studi Magister Kenotariatan \\ Fakultas Hukum \\ Universitas Narotama Surabaya \\ Email: Eriklembah85@gmail.com
}

\section{Triyanto ${ }^{2}$}

Program Studi Magister Kenotariatan

Fakultas Hukum

Universitas Narotama Surabaya

Email: triyantoryan2@gmail.com

\author{
Rusdiyanto Sesung ${ }^{3}$ \\ Program Studi Magister Kenotariatan \\ Fakultas Hukum \\ Universitas Narotama Surabaya \\ Email: rusdianto@narotama.ac.id
}

\section{ABSTRAK}

Notaries as public officials have a duty to make an authentic deed for the needy, and generally speaking, Notary is the only general official who has a substantial legal authority to make almost all authentic deeds. Pursuant to Article 1 of Law Number 30 Year 2004 regarding Notary Position as amended by Law Number 2 Year 2014 regarding Amendment of Law Number 30 Year 2004 regarding Notary Public Official that Notary is a public official authorized to make authentic deed and other authority as referred to in this law and Article 15 paragraph (2)

\footnotetext{
${ }^{1}$ Mahasiswa Fakultas Hukum Narotama

${ }^{2}$ Mahasiswa Fakultas Hukum Narotama

${ }^{3}$ Dosen Fakultas Hukum Narotama
} 
letter $\mathrm{g}$ states that the Notary is also authorized to make a deed of minutes of the auction based on the provisions of Article 1868 of the Civil Code (Civil Code) is an Authentic Act. One of the special characteristics of an Auction of Minutes Act is made by the Auction Officer appointed by the Minister of Finance to make the Auction Minutes at the end of the auction process stipulated in the PMK No. a. 93 / PMK.06 / 2010 concerning the Auction Guide. The existence of Deed of Minutes of Auction is very important in the auction process of both movable and immovable objects. The strength of the proof consists of the power of proof of birth, formal and material as set forth in Article 1868 of the Civil Code. Then a question arises as to whether the Auction Deed of Acts is authenticated by an Authentic Deed. According to Article 1868 of the Civil Code, an authentic deed is a deed in the form prescribed by law, made by or in the presence of the ruling public officials for it in the place where the deed is made. Whether the auction form of the auction is determined by law. Thus whether the auction treatise which is the legal product of the auction official is equal to the authentic deed. This is interesting to be observed and investigated further, because there is a conflict of norm between UUJN Number 2 Year 2014 about Notary and Auction Regulations (Vendu Reglement). The consequence of the law is because the Auction of Minutes Deed made by the Auction Officer based on the regulation vendor is not based on the Act so that the authenticity of the Auction Minutes Act made by the Auction Officer creates a contradiction of the conception of authentic deed based on BW and UUJN.

Keywords: Authentic Deed, Deed of Auction Minutes, Authority of Notary Public.

\section{A. PENDAHULUAN}

Notaris sebagai Pejabat Umum, dalam hal ini dihubungkan dengan Pasal 1868 Kitab Undang-Undang Hukum Perdata yang menyatakan bahwa: "Suatu akta yang sedemikian, yang dibuat dalam bentuk yang ditentukan oleh Undang-Undang oleh atau di hadapan pejabat umum yang berwenang untuk itu, di tempat di mana akta itu dibuat". Notaris dalam jabatannya sesungguhnya merupakan instansi yang dengan aktaaktanya menimbulkan alat-alat pembuktian tertulis dengan mempunyai sifat otentik ${ }^{4}$.Akta otentik memiliki arti yang sangat penting di dalam kehidupan bermasyarakat dewasa ini karena mampu menjadi alat bukti yang mempunyai kekuatan pembuktian sempurna. Hal tersebut sesuai dengan rumusan Pasal 1870 Kitab Undang-Undang Hukum Perdata yang menyatakan bahwa suatu akta Otentik memberikan diantara para pihak beserta para ahli warisnya atau orang-orang yang mendapat hak dari mereka, suatu bukti yang lengkap atau sempurna dan mengikat tentang apa yang dimuat di dalamnya, ${ }^{5}$

\footnotetext{
${ }^{4}$ R. Soegando Notodisoerjono, Hukum Notariat di Indonesia Suatu Penjelasan, Raja Grafindo Persada, Jakarta, 1993, hal, 7.

${ }^{5}$ Kitab Undang-Undang Hukum Perdata
} 
dalam arti bahwa apa yang ditulis dalam akta itu harus dapat dipercaya oleh hakim, yaitu harus dianggap sebagai yang benar, selama ketidakbenarannya itu tidak ada pihak lain yang dapat membuktikan sebaliknya dan ia memberikan suatu penambahan pembuktian lain. Demi mengakomodir kebutuhan masyarakat terhadap kebutuhan akan alat bukti yang bersifat otentik Pemerintah membagi sebagian dari tugasnya tersebut kepada Notaris.

Berdasarkan ketentuan Pasal 15 Undang-Undang Nomor 2 Tahun 2014 tentangJabatan Notaris adalah Notaris berwenang membuat akta otentik mengenai semua perbuatan, perjanjian, dan penetapan yang diharuskan oleh peraturan perundangundangan dan/atau yang dikehendaki oleh yang berkepentingan untuk dinyatakan dalam Akta otentik, menjamin kepastian tanggal pembuatan Akta, menyimpan Akta, memberikan grosse, salinan dan kutipan Akta, semuanya itu sepanjang pembuatan Akta itu tidak juga ditugaskan atau dikecualikan kepada pejabat lain atau orang lain yang ditetapkan oleh undang-undang.

Salah satu ciri khusus sebuah Akta Risalah Lelang yaitu dibuat oleh Pejabat Lelang yang diangkat oleh Menteri Keuangan untuk membuat Risalah Lelang pada akhir proses lelang diatur dalam PMK No. 27/PMK.06/2016 tentang Petunjuk Pelaksanaan Lelang. Keberadaan Akta Risalah Lelang sangat penting dalam proses lelang baik benda bergerak maupun benda tidak bergerak. Kekuatan pembuktiannya terdiri dari kekuatan pembuktian lahir, formil dan materil sebagaimana telah diatur dalam Pasal 1868 Kitab Undang-Undang Hukum Perdata.Maka timbul suatu pertanyaan apakah Akta Risalah Lelang termaksud Akta Otentik. Menurut Pasal 1868 Kitab Undang-Undang Hukum Perdata suatu akta otentik ialah akta yang didalam bentuk yang ditentukan oleh undang-undang, dibuat oleh atau dihadapan pegawai-pegawai umum yang berkuasa untuk itu ditempat dimana akta dibuatnya ${ }^{6}$. Apakah bentuk akta risalah lelang tersebut telah ditentukan oleh undang-undang. Dengan demikian apakah risalah lelang yang merupakan produk hukum pejabat lelang statusnya sama dengan akta otentik.

Hal ini menarik untuk dicermati dan diteliti lebih jauh, sebab terjadi konflik norma antara UUJN Nomor 2 Tahun 2014 tentang Jabatan Notaris dan Peraturan Lelang (Vendu Reglement) yang ditindaklanjuti dengan Instruksi Lelang (Vendu Instructie) dengan Peraturan Menteri

${ }^{6}$ Ibid 
Keuangan Nomor 27/PMK.06/2016tentang Petunjuk Pelaksanaan Lelang, Peraturan Menteri Keuangan Nomor 158/PMK.06/2013 tentang Pejabat Lelang Kelas I dan Peraturan Menteri Keuangan Nomor 159/PMK.06/2013 Tentang Pejabat Lelang Kelas II yang merupakan peraturan pelaksana dari Peraturan Lelang dan Instruksi Lelang tersebut di atas.

Dengan demikian maka berdasarkan ketentuan tersebut Berdasarkan argumentasi tersebut hal ini menjadi dasar penulis mengajukan penelitian tentang Karakteristik Akta RisalahLelang Sebagai Akta Otentik.

\section{B. METODE PENELITIAN}

Mengingat ini merupakan penelitian hukum normatif, maka metode yang digunakan adalah metode penelitian hukum yang bertujuan untuk mencari pemecahan atas isu hukum yang timbul didalamnya, sehingga hasil yang akan dicapai kemudian adalah memberikan preskripsi mengenai apa yang seyogyanya atas isu yang diajukan.Peter Mahmud Marzuki dalam bukunya Penelitian Hukum, ${ }^{7}$ menyatakan bahwapenelitian hukum merupakan proses untuk menemukan aturan hukum, prinsipprinsip hukum, maupun doktrin-doktrin hukum guna menjawab isu hukum yang

${ }^{7}$ Peter Mahmud Marzuki, Penelitian Hukum, Kencana Prenada Media Group,Jakarta, 2005, h. 35 dihadapi. Lebih lanjutdikatakan dalam melakukan penelitian hukumlangkahlangkah yang dilakukan adalah sebagai berikut ${ }^{8}$

a. Mengidentifikasikan fakta hukum dan mengeliminir hal-hal yang tidak relevan untuk menetapkan isu hukum yang hendak dipecahkan;

b. Pengumpulan bahan-bahan hukum dan sekiranya dipandang mempunyai relevansi juga bahan-bahan non hukum;

c. Melakukan telaah atas isu yang diajukan berdasarkan bahan-bahan yang telah dikumpulkan;

d. Menarik kesimpulan dalam bentuk argumentasi yang menjawab isu hukum;

e. Memberikan preskripsi berdasarkan argumentasi yang telah dibangun di dalam kesimpulan.

\section{Pendekatan Masalah}

\section{Pendekatan Perundang-undangan}

Pendekatan perundang-undangan (statute approach), yaitu pendekatan dengan menelaah semua peraturan perundangundangan yang bersangkutpaut dengan permasalahan (isu hukum) yang sedang dihadapi. ${ }^{9}$ Pendekatan perundang-undangan ini dilakukan dengan melihat konsistensi/kesesuaian antara Undang-

\footnotetext{
${ }^{8}$ Ibid., h. 171-172

Peter Mahmud Marzuki,Penelitian Hukum, Kencana Prenada Media, Jakarta, 2010, hal. 59.
} 
Undang Jabatan Notaris dengan peraturan lain yang mendasarinya.

\section{Pendekatan Konseptual}

Pendekatan konseptual (Conseptual Approach), yaitu pendekatan yang beranjak dari pandangan-pandangan dan doktrindoktrin yang berkembang di dalam ilmu hukum. Pendekatan ini menjadi penting sebab pemahaman terhadap pandang/doktrin yang berkembang dalam ilmu hukum dapat menjadi pijakan untuk membangun argumentasi hukum ketika menyelesaikan isu hukum yang dihadapi. Pandangan/doktrin akan memperjelas ideide dengan memberikan pengertianpengertian hukum, konsep hukum, maupun asas hukum yang relevan dengan permasalahan. $^{10}$

\section{Sumber Bahan Hukum}

\section{Bahan hukum primer}

Bahan hukum primer diperoleh dari Undang-Undang yang terkait dengan pokok permasalahan yaitu :

a. Undang-Undang Dasar Negara Republik Indonesia Tahun 1945;

b. Undang-Undang Republik Indonesia Nomor 2 Tahun 2014 tentang Perubahan

${ }^{10} \mathrm{Ibid}$, hal. 97 atas Undang-Undang Nomor 30 Tahun 2004 tentang Jabatan Notaris;

c. Peraturan Menteri Keuangan Nomor 175/PMK. 06/2010 tentang Pejabat Lelang Kelas II;

d. Peraturan Menteri Keuangan (PMK) Nomor. 93/PMK. 06/2010 tentang Petunjuk Pelaksana Lelang.

\section{Bahan hukum sekunder}

Penelitian ini mengunakan literaturliteratur yang berhubungan dengan permasalahan dalam penelitian berupa bukubuku, artikel-artikel ilmiah, makalah berbagai pertemuan ilmiah, hasil seminar, tesis dan disertasi.

\section{Prosedur Pengumpulan dan Pengolahan} Bahan Hukum

Prosedurpengumpulan bahan hukum dalam penelitian ini adalah pertama-tama peneliti menetapkan isu hukum yang menjadi acuan pokok dalam pembahasan selanjutnya dari isu hukum tersebut, peneliti mencari dan mengumpulkan bahan hukum primer dan bahan hukum sekunder. Selanjutnya bahan hukum yang telah terkumpul tersebut diolah dengan cara mengklarifikasikan berdasarkan isu hukum yang digunakan dan mensistematisasi kemudian dilakukan analisis dan disimpulkan. 


\section{Analisis Bahan Hukum}

Analisishukum dilakukan dengan cara melakukan invetarisasi terhadap bahanbahan hukum, kemudian melakukan klasifikasi atau bahan-bahan hukum tersebut sesuai dengan permasalahan yang diajukan, kemudian disistematisasi, di interpretasi, dianalisis dan disimpulkan isu hukum yang sudah dikemukakan.

\section{PEMBAHASAN}

\section{KEDUDUKAN AKTA RISALAH}

\section{LELANG}

\section{Karakteristik Akta Otentik}

\section{Akta Otentik}

Akta otentik adalah akta yang dibuat oleh pejabat yang diberi wewenang untuk itu oleh penguasa menurut ketentuan yang telah ditetapkan, baik dengan atau tanpa bantuan dari pihak-pihak yang berkepentingan, yang mencatat apa yang dimintakan untuk dimuat di dalamnya oleh pihak-pihak yang berkepentingan. Akta otentik tersebut memuat keterangan seorang pejabat yang menerangkan tentang apa yang dilakukannya atau dilihat di hadapannya.

Dalam pasal 1868 Kitab Undang-Undang Hukum Perdata yang dimaksud dengan "akta otentik adalah suatu akta yang di buat dalam bentuk yang ditentukan oleh undangundang oleh/atau dihadapan pejabat umum yang berwenang untuk maksud itu, ditempat di manaakta dibuat".

Dalam Pasal 165 Herzien Inlandsch Reglement (selanjutnya disebut H.I.R.) atau Reglement Indonesia yang diperbaharui (selanjutnya disebut R.I.B.) disebutkan bahwa "Akta otentik yaitu suatu akta yang dibuat oleh atau di hadapan pejabat yang diberi wewenang untuk itu, merupakan bukti yang lengkap antara para pihak dan para ahli warisnya dan mereka yang mendapat hak dari padanya tentang apa yang tercantum di dalamnya sebagai pemberitahuan belaka, akan tetapi akan terakhir ini hanyalah sepanjang yang diberitahukan itu erat hubungannya dengan pokok dari pada akta". Akta itu disebut otentik apabila memenuhi 3 unsur, yaitu : ${ }^{11}$

1. dibuat dalam bentuk menurut ketentuan undang-undang;

2. dibuat oleh atau dihadapan pejabat umum;

3.pejabat umum itu harus berwenang untuk itu ditempat akta itu dibuat.

Dikemukakan pula oleh Irawan Soerodjo, bahwa ada 3 (tiga) unsur esenselia agar

\footnotetext{
${ }^{11}$ Nurul Muslimah Kurniati, Notaris Dan Akta Notaris, tedapat dalam http://notarisnurulmuslimahkurniati.blogspot.co.id/ 2009/04/notaris-dan-akta-notaris.html
} 
terpenuhi syarat formal suatu akta otentik, yaitu $^{12}$ :

1. Di dalam bentuk yang ditentukan oleh undang-undang;

2. Dibuat oleh dan di hadapan Pejabat Umum;

3. Akta yang dibuat oleh atau dihadapan Pejabat Umum yang berwenang untuk itu dan di tempat dimana akta itu dibuat.

Menurut Habib Adjie dalam bukunya "Memahami dan menguasai teori akta notaris ragam awal akta, komparisi dan akhir akta" Pasal 1868 B.W ${ }^{13}$.merupakan sumber untuk otentisitas akta Notaris juga merupakan dasar legalitas eksistensi akta Notaris, dengan syarat-syarat sebagai berikut :

12 Irawan Soeradjo, Kepastian Hukum Hak Atas Tanah Di Indonesia, Arkola, Surabaya, 2003, hal. 148.

${ }^{13}$ Jika secara normatif ketentuan Pasal 1868 BW tersebut dijadikan untuk parameter untuk menilai akta PPAT dan Risalah Lelang. Dengan parameter Pasal 1868 BW tersebut menilai akta PPAT dan akta Risalah Lelang belum termasuk dalam kategori akta Otentik, karena sampai saat ini belum ada Unang-undang Jabatan Pejabat Pembuat Akta Tanah (UUPPAT) dan Undang-undang Pejabat Lelang (UUPL). Sehingga akta PPAT dan Risalah Lelang masih dalam Quasi Akta Otentik yang pembuktiannya tergantung pada putusan hakim jika dipermasalahkan.Jika tidak dipermasalahkan tetap mengikat para pihak yang membuatnya. a. akta itu harus dibuat oleh (door) atau dihadapan (ten overstaan) seorang Pejabat Umum.

b. akta itu harus dibuat dalam bentuk yang ditentukan oleh undang-undang;

c. Pejabat Umum oleh atau di hadapan siapa akta itu dibuat, harus mempunyai wewenang untuk membuat akta tersebut;

Menurut C.A. Kraan akta otentik mempunyai ciri-ciri sebagai berikut ${ }^{14}$ :

a. Suatu tulisan, dengan dibuat sematamata untuk dijadikan bukti atau suatu bukti dari keadaan sebagaimana disebutkan di dalam tulisan dibuat dan di nyatakan oleh pejabat yang berwenang. Tulisan tersebut turut ditandatangani oleh atau hanya ditandatangani oleh pejabat yang bersangkutan saja;

b. suatu tulisan sampai ada bukti sebaliknya, dianggap berasal dari pejabat yang berwenang;

c. Ketentuan perundang-undangan yang harus dipenuhi; ketentuan tersebut mengatur tata cara pembuatannya (sekurangkurangnya memuat ketentuan-ketentuan mengenai tanggal, tempat dibuatnya akta suatu tulisan, nama dan kedudukan/jabatan

\footnotetext{
${ }^{14}$ C.A. Kraan, De Authentieke Akte, Gouda Quint BV, Arnhem 1984, hal.143 dan 201 dalam Herlien Budiono, op cit., hal. 3-4.
} 
pejabat yang membuatnya c.q. data dimana dapat diketahui mengenai hal-hal tersebut).

d. Seorang pejabat yang diangkat oleh Negara dan mempunyai sifat dan pekerjaan yang mandiri (onafhankelijk-independence) serta tidak memihak (onpartijdigheidimpartiality) dalam menjalankan jabatannya; e. Pernyataan fakta atau tindakan yang disebutkan oleh pejabat adalah hubungan hukum di dalam bidang hukum privat.

Akta Otentik merupakan alat bukti yang sempurna, sebagaimana dimaksud dalam pasal 1870 Kitab Undang-Undang Hukum Perdata.Ia memberikan diantara para pihak termasuk para ahli warisnya atau orang yang mendapat hak dari para pihak itu suatu bukti yang sempurna tentang apa yang diperbuat/ dinyatakan dalam akta ini. Ini berarti mempunyai kekuatan bukti sedemikian rupa karena dianggap melekatnya pada akta itu sendiri sehingga tidak perlu dibuktikan lagi dan bagi hakim itu merupakan "Bukti Wajib/Keharusan".

Suatu akta merupakan akta otentik, maka akta tersebut mempunyai 3 (tiga) fungsi terhadap para pihak yang membuatnya yaitu $:^{15}$

15 Salim HS, Hukum Kontrak-Teori dan Teknik Penyusunan Kontrak, Sinar Grafika, Jakarta, 2006, hlm.43 a. sebagai bukti bahwa para pihak yang bersangkutan telah mengadakan perjanjian tertentu;

b. sebagai bukti bagi para pihak bahwa apa yang tertulis dalam perjanjian adalah menjadi tujuan dan keinginan para pihak.

c. sebagai bukti kepada pihak ketiga bahwa tanggal tertentu kecuali jika ditentukan sebaliknya para pihak telah mengadakan perjanjian dan bahwa isi perjanjian adalah sesuai dengan kehendak para pihak.

Berdasarkan definisi tersebut diketahui bahwa suatu akta dapat dikatakan sebagai akta otentik harus memenuhi syarat-syarat yaitu dibuat dalam bentuk yang ditentukan Undang-Undang, dibuat oleh seorang pejabat atau pegawai umum, dan pejabat atau pegawai umum tersebut harus berwenang untuk membuat akta tersebut ditempat di mana akta dibuat.

Dari ketentuan tersebut di atas, suatu akta dikatakan sebagai akta otentik (mempunyai otentisitas) bilamana memenuhi hal atau syarat-syarat berikut:

a. Bentuk dan susunan (vorm) aktanya dibuat sesuai dengan yang ditentukan oleh undang-undang (wettelijkje vorm). 
b. Akta itu harus dibuat oleh (door) atau dihadapan (tenoverstaan) seorang Pejabat Umum;

c. Pejabat umum yang membuat akta tersebut haruslah pejabat yang mempunyai wewenang untuk membuat akta itu sesuai dengan wilayah kerjanya.

\subsubsection{Akta di Bawah Tangan}

Akta di bawah tangan mempunyai kekuatan pembuktian sepanjang para pihak mengakuinya atau tidak ada penyangkalan dari salah satu pihak $^{16}$, jika para pihak mengakuinya, maka akta di bawah tangan tersebut mempunyai kekuatan pembuktian yang sempurnah sebagaimana akta otentik ${ }^{17}$, jika ada salah satu pihak tidak mengakuinya, beban pembuktian diserahkan kepada pihak yang menyangkal akta tersebut, dan penilaian penyangkalan atas bukti tersebut diserahkan kepada hakim ${ }^{18}$.

16 Sebagai contoh Putusan Mahkamah Agung Republik Indonesia Nomor 775 K/Sip/1971, tanggal 6 oktober 1971, menegaskan bahwa surat (surat jual beli) yang diajukan dalam persidangan, kemudian disangkal oleh pihak lawan, dan tidak dikuatkan dengan alat bukti lainnya, maka surat (jual beli tanah) tersebut dinilai sebagai alat bukti yang lemah dan belum sempurna. M. Ali Boediarto, op cit., hal. 145.

${ }^{17}$ Pasal 1875 B.W.

${ }^{18}$ Peradilan Perdata di Indonesia menganut sistem hukum pembuktian berdasar pada asas negatif wettelijk bewijsleer. Hal ini terlihat dalam Pasal 249 jo 298 H.I.R. dan tidak memakai sistem vrijbewijsleer yang menitikberatkan pada keyakinan hakim belaka. Hal ini dilarang oleh undang-undang (Putusan Mahkamah Agung Republik Indonesia Nomor 583 K/Sip/1970,
Akta bawah tangan bagi hakim merupakan "Bukti Bebas" karena akta di bawah tangan ini baru mempunyai kekuatan bukti materiil setelah dibuktikan kekuatan formilnya. Sedang kekuatan pembuktian formilnya baru terjadi, bila pihak-pihak yang bersangkutan mengakui akan kebenaran isi dan cara pembuatan akta itu.

Akta yang termasuk akta di bawah tangan yaitu :

a. Legalisasi, adalah akta di bawah tangan yang belum ditandatangani, diberikan kepada notaris dan dihadapan notaris ditandatangani oleh para pihak yang bersangkutan, setelah isi akta dijelaskan oleh notaris kepada mereka. Pada legalisasi, tanda tangannya dilakukan dihadapan yang melegalisasi.

b. Waarmeken, adalah akta di bawah tangan yang didaftarkan untuk memberikan tanggal yang pasti. Akta yang sudah ditandatangani diberikan kepada notaris untuk didaftarkan dan diberi tanggal yang pasti.Pada waarmeken tidak menjelaskan mengenai siapa yang menandatangani dan apakah

tanggal 10 Februari 1971), M. Ali Boediarto, op cit., hal. 136. 
penandatangan memahami isi akta, hanya mengenai kepastian tanggal saja dan tidak ada kepastian tandatangan.

\subsection{Otentisitas Pada Akta Risalah Lelang}

\subsubsection{Risalah Lelang}

Sebagai bukti pelaksanaan lelang, Pejabat Lelang wajib membuat berita acara lelang, yang dinamakan dengan "risalah lelang". Kewajiban membuat risalah lelang tersebut ditentukan dalam Pasal 85 ayat (1) Peraturan Menteri Keuangan Nomor 27/PMK.06/2016 tentang Petunjuk Pelaksanaan Lelang, yang menyatakan bahwa "Pejabat Lelang yang melaksanakan lelang wajib membuat Risalah Lelang".

Setiap pelaksanaan lelang yang dilakukan oleh Pejabat Lelang harus dibuatkan Berita Acara Lelang yang disebut Risalah Lelang, sesuai dengan Pasal 35 Vendu Reglement yang mengatakan "Dari setiap penjualan dimuka umum oleh Pejabat Lelang atau kuasanya, selama dalam penjualan, untuk tiap hari pelanggan atau penjualan dibuat berita acara tersendiri".Dari ketentuan ini, maka Pejabat Lelang yang melaksanakan setiap lelang diwajibkan untuk membuat berita acara lelang, yang kemudian dinamakan dengan istilah "risalah lelang”.

Ketentuan Pasal 35 Vendu Reglement tersebut "mengatur "risalah lelang" sama artinya dengan "berita acara lelang”, yang merupakan landasan autentifikasi penjualan lelang, berita acara lelang mencatat segala peristiwa yang terjadi pada penjualan lelang ${ }^{19}$. Sementara itu menurut ketentuan dalam Pasal 1 angka 35 Peraturan Menteri Keuangan Nomor 27/PMK.06/2016 tentang Petunjuk Pelaksanaan Lelang, "Risalah Lelang" adalah berita acara pelaksanaan lelangyang dibuat oleh Pejabat Lelang yang merupakan akta otentik dan mempunyai kekuatan pembuktian sempurna. Dalam berita acara lelang tersebut berisikan uraian mengenai segala sesuatu yang terkait dengan pelaksanaan pelelangan atau penjualan umum yang dilakukan oleh Pejabat Lelang.

Risalah lelang itu harus memuat apa, mengapa, dimana, bila, bagaimana, dan siapa-siapa yang terlibat dalam pelaksanaan lelang. Apa yang dilelangkan menjelaskan tentang objek

19 M. Yahya Harahap. 1994. Ruang Lingkup Permasalahan Eksekusi Bidang Perdata. Jakarta: Gramedia, hlm. 187. 
atas barang yang dilelangkan. Mengapa dilakukan pelelangan menjelaskan latar belakang sampai timbulnya lelang tersebut.Hal ini pentingsekali dijelaskan dalam lelang eksekusi.Kemudian di mana dilelangkan menjelaskan di mana dilaksanakan lelang tersebut dan kapan lelang dilaksanakan. Bagaimana pelaksanaan lelang menjelaskan proses terjadinya penawaran sampai dengan ditunjuknya pembeli lelang. Terakhir siapa-siapan yang terlibat dalam lelang, siapa pemohon atau penjual lelang, siapa penawaran, dan siapa pembeli lelang. ${ }^{20}$

Syarat untuk disebut sebagai akta otentik adalah apabila Risalah Lelang tersebut memenuhi unsur-unsur seperti yang disebutkan dalam Pasal 1868 KUH Perdata yang menyatakan "Suatu akta otentik ialah suatu akta yang didalam bentuk yang ditentukan oleh undang-undang, dibuat oleh atau dihadapan pegawai-pegawai umum yang berkuasa untuk itu ditempat dimana akta dibuatnya", Sedangkan Risalah Lelang dibuat berdasarkan ketentuan sebagai berikut:

${ }^{20}$ F.X. Ngadijarmo, Nunung Eko Laksito, dan Isti Indri Listiani, op.cit., hlm. 354-355
1. Dibuat menurut Undang-undang (Pasal 37-39 Vendu Reglement).

2. Dibuat oleh atau dihadapan Pejabat Lelang (Pasal 1a dan Pasal 35 Vendu Reglement)

3. Wilayah kerja Pejabat Lelang ditentukan oleh Menteri Keuangan.

Dengan demikian unsur-unsur sebagai suatu akta otentik telah dipenuhi oleh Risalah Lelang. Maka Risalah Lelang dapat digunakan sebagai alat bukti yang sempurna, sesuai dengan Pasal 1870 KUHPerdata yang menyatakan "Suatu akta otentik memberikan diantara para pihak beserta ahli waris- ahli warisnya atau orangorang yang mendapat hak dari mereka, suatu bukti yang sempurna tentang apa yang dimuat didalamnya". Sehingga para pihak akan terlindungi dari perbuatan hukum pihak ketiga.

Kekuatan pembuktian Akta Risalah Lelang bersumber pada ketentuan pasal 35 VR jo.pasal 1868KUHPerdata dimana disebutkan bahwa suatu akta otentik adalah suatu akta yang buat dalam bentuk yang ditentukan oleh undang-undang dibuat oleh Pejabat Umum yang berwenang untuk itu di tempat dimana akta itu dibuat. Berdasarkan ketentuan pasal 1868 KUHPerdata tersebut 
terdapat 3 unsur yang harus dipenuhi agar

Risalah Lelang memiliki ciri otentikyaitu :

1. Akta tersebut dibuat dan diresmikan dalam bentuk yang ditentukan oleh undang-undang.

Akta tersebut harus dibuat dalam bentuk yang telah ditentukan oleh undang-undang, terkait Risalah Lelang sebagai akta otentik harus dibuat dalam bentuk yang telah ditentukan oleh undangundang di bidang lelang, yang dimaksud bentuk adalah format akta tersebut. Mengenai format pembuatan Risalah Lelang telah diatur dalam pasal 37, 38, 39 VR jo. Pasal 53, 54, 55, 56, 57, 58, dan 59 Peraturan Menteri Keuangan Nomor 40/PMK.07/2006 tentang Petunjuk Pelaksanaan Lelang.

2. Akta tersebut dibuat oleh atau di hadapan Pejabat Umum.

Pejabat Umum adalah organ negara yang dilengkapi dengan kekuasaan umum, berwenang menjalankan sebagian dari kekuasaan negara untuk membuat alat bukti tertulis dan otentik dalam bidang hukum perdata.Berkaitan dengan pelaksanaan lelang, Risalah Lelang sebagai suatu akta otentik harus dibuat oleh Pejabat Umum yang berwenang yaitu Pejabat Lelang.
3. Akta tersebut dibuat oleh atau di hadapan Pejabat yang berwenang membuatnya di tempat di mana akta itu dibuat.

Akta Otentik harus dibuat dalam wilayah kewenangan dari pejabat umum yang bersangkutan,artinya dalam pembuatan akta otentik harus diperhatikan daerah hukum atau wilayah jabatandimana pejabat umum itu berwenang.Hal ini berarti bahwa akta otentiktidak boleh dibuat oleh pejabat umum yang tidak mempunyai kewenangan untuk itu dan di tempat itu.Pembuatan akta Risalah Lelang oleh Pejabat Lelang juga harus memperhatikan wilayah kerja yang telah ditentukan sesuai dengan yang ditetapkan dalam Surat Keputusan Pengangkatan Pejabat Lelang yang dikeluarkan oleh Direktur Jenderal Kekayaan Negara.

Berdasarkan uraian tersebut di atas, dapat disimpulkan bahwa Risalah Lelang merupakan akta Otentikkarena telah memenuhi unsur-unsur atau syarat-syarat Akta Otentik sebagaimana yang ditetapkan dalam pasal 1868 KUHPerdata, Risalah Lelang sebagai akta otentik merupakan alat bukti yang sempurna, yang mempunyai kekuatan pembuktian :

a. Lahiriah, yaitu bahwa akta itu sendiri mempunyai kekuatan atau kemampuan 
untuk membuktikan sendiri sebagai akta otentik, mengingat kehadirannya itu telah sesuai dengan ketentuan akta otentik dalam KUHPerdata

b. Formal, yaitu bahwa akta itu membuktikan kebenarannya daripada yang disaksikan, dilihat, didengar dan juga dilakukan oleh Pejabat Lelang sebagai Pejabat Umum dalam menjalankan jabatannya, terjamin kebenaran dari tanggalnya, tanda tangan yang terdapat dalam akta itu, identitas para pihak dan orang-orang yang hadir, serta kebenaran tempat dimana akta itu dibuat.

\section{KEKUATAN PEMBUKTIAN PADA AKTA RISALAH LELANG}

\subsection{Kekuatan Pembuktian Akta Otentik}

Dalam Hukum (Acara) Perdata, alat bukti yang sah atau yang diakui oleh hukum, terdiri dari ${ }^{21}$ :

a. bukti tulisan;

b. bukti dengan saksi-saksi;

21 Pasal 138, 165, 167 HIR, 164, 285-305 Rbg, S. 1867 nomor 29, Pasal 1867-1894 B.W. Meurut Putusan Mahkamah Agung Republik Indonesia, dengan Putusan tanggal 10 April 1957, nomor 213 K/Sip/1955, bahwa penglihatan hakim dalam persidangan atas alat bukti tersebut, adalah merupakan pengetahuan hakim sendiri yang merupakan usaha pembuktian. M. Ali Boediarto, ibid., hlm. 157. c. persangkaan-persangkaan;

d. pengakuan; dan

e. sumpah.

Pembuktian bertujuan untuk menetapkan hukum diantara kedua belah pihak yang menyangkut suatu hak sehingga diperoleh suatu kebenaran yang memiliki nilai kepastian, keadilan, dan kepastian hukum.Dalam pembuktian, para pihak memberi dasar-dasar yang cukup kepada hakim dilarang melampaui batas yang diajukan oleh para pihak yang berperkara.

Pembuktian dengan tulisan dilakukan dengan tulisan-tulisan otentik maupun dengan tulisan-tulisan di bawah $\operatorname{tangan}^{22}$.Tulisan-tulisan otentik berupa akta otentik, yang dibuat dalam bentuk yang sudah ditentukan oleh undang-undang, dibuat di hadapan pejabat-pejabat (pegawai umum) yang diberi wewenang dan di tempat dimana akta tersebut di buat ${ }^{23}$.Tulisan di bawah tangan atau disebut juga akta di bawah tangan dibuat dalam bentuk yang tidak ditentukan oleh undang-undang, tanpa perantara atau tidak di hadapan Pejabat umum yang berwenang ${ }^{24}$.Baik akta otentik maupun akta di bawah tangan dibuat dengan

\footnotetext{
${ }^{22}$ Pasal 1867 BW.

${ }^{23}$ Pasal 1868 BW.

${ }^{24}$ Pasal $1874 \mathrm{BW}$.
} 
tujuan untuk dipergunakan sebagai alat bukti.

Notaris berwenang membuat akta Risalah Lelang sebagaimana disebutkan pasal 15 ayat (2) huruf g UUJN, maka Notaris bukan lagi sebagai Notaris akan tetapi terlebih dahulu melepaskansementara atau meninggalkan kedudukannya sebagai Notaris, sehingga Notaris hanya cukup disebut sebagai Pejabat Lelang saja. Dasar hukum yang mengatur Notaris dapat menjabat sebagai Pejabat lelang diatur dalam pasal 7 VI jo. Peraturan Menteri Keuangan Republik Indonesia Nomor 175/PMK.06/2010 tentang Pejabat Lelang Kelas II. Notaris sepanjang melaksanakan tugas jabatan sebagai Pejabat Lelang harus berpijak dengan tata cara yang sudah diatur dalam VR dan Peraturan-Peraturan Menteri Keuangan, Notaris tidak dapat membuat akta Risalah Lelang sebagaimana layaknya akta Notariil karena notaris saat menjalankan wewenangnya sebagai Pejabat Lelang meninggalkan jabatannya sebagai Notaris.

Sebagaimana telah dijelaskan sebelumnyabahwa akta Risalah Lelang dikatakan autentik dapat dilihat dari cara pembuatan Risalah Lelang tersebut. Akta Risalah Lelang dikatakan akta autentik apabila pembuatan atau terjadinya akta tersebut dilakukan oleh dan atau di hadapan seorang Pejabat Umum yang berwenang untuk membuatnya yaitu Pejabat Lelang. Dengan demikian akta Risalah Lelang yang dibuat oleh Notaris dalam kedudukannya sebagai Pejabat Lelang adalah sah dan mempunyai kekuatan hokum yang mengikat sebagai suatu akta yang autentik, karena Risalah Lelang yang dibuat oleh Notaris dalam kedudukannya sebagai Pejabat Lelang telah memenuhi unsur sebagai akta autentik, dan Notaris sendiri dalam kedudukannya sebagai Pejabat Lelang menurut Peraturan Lelang berwenang untuk membuatnya.

Akta Risalah Lelang yang dibuat oleh Notaristelah memenuhi syarat sebagai suatu akta yang autentik karena telah dibuat oleh Notaris namun dalam kapasitasnya sebagai Pejabat lelang Kelas II dan telah mengikuti ketentuan peraturan perundangundangan yang memang mengatur dalam bidang lelang.Akta Risalah Lelang yang dibuat Notaris dalam kedudukannya sebagai Pejabat Lelang memiliki kekuatan pembuktian yang sempurna dan mengikat.

Menurut Penulis, Bukti tulisan ditempatkan sebagai buktiutama, yang mengarah kepada kebenaran formal. Pembuktian dengan tulisan dilakukan dengan tulisan otentik maupun dengan 
tulisan-tulisan dibawah tangan.Tulisantulisan otentik berupa akta otentik yang dibuat dalam bentuk yang sudah ditentukan oleh undang-undang, dibuat di hadapan pejabat-pejabat (pegawai umum) yang diberi wewenang dan ditempat akta tersebut dibuat.

Unsur-unsur dalam Pasal 1868 Kitab Undang-Undang Hukum Perdata apabila diterapkan dalam Risalah Lelang maka terdapat pembuktian bahwa risalah Lelang merupakan Akta Otentik, yaitu:

1. Risalah Lelang dibuat dalam bentuk yang ditentukan Undang-Undang (Pasal 37, 38, 39, VenduReglement/Peraturan Lelang);

2. Pembuatan Risalah Lelang dilakukan dihadapan atau oleh Pejabat Lelang;

3. Pejabat Lelang yang membuat Akta Risalah Lelang memiliki wewenang:

a. Membuat Akta yang dibuatnya (Pejabat Lelang kelas II berwenang membuat Risalah Lelang dan jenis Lelang Sukarela)

b. Saat akta itu dibuat (masih aktif sebagai Pejabat Lelang atau tidak)

c. Dimana akta itu dibuat (terkait dengan wilayah jabatan) Untuk siapa akta itu dibuat (untuk kepentingan pengguna jasa lelang).

\section{Perbandingan Akta Otentik dan Akta}

Risalah Lelang

Menurut hukum, bahwa Risalah Lelang termasuk kategori akta otentik. Syarat-syarat sebagai Akta adalah:

1. Surat harus ditanda tangani

2. Surat itu harus memuat peristiwa yang menjadi dasar sesuatu hak atas suatu perikatan.

3. Surat itu diperuntukkan sebagai alat bukti ${ }^{25}$.

Risalah Lelang jika dihubungkan dengan definisi akta sebagaimana telah disebutkan diatas yaitu sebagai berikut:

1. Bahwa setiap Risalah Lelang harus ditandatangani oleh para pihak baik Pejabat Lelang, Penjual maupun Pembeli(vide Pasal 38 Vendu Reglement):

2. Isi Risalah Lelang adalah Berita Acara dari peristiwa atau apa yang terjadi dan dialami para pihak yaitu jual beli dimuka umum/lelang. Sehingga isi Risalah Lelang tersebut merupakan rangkaian peristiwa yang menjadi dasar sesuatu hak atas suatu perikatan.

3. Risalah Lelang dari semula dibuat oleh pejabat lelang memang dimaksudkan

${ }^{25}$ F. X. Ngadijarno (Dkk),Op.Cit., hlm. 259. 
sebagai bukti yang sah sesuai pengertian dari Risalah Lelang itu sendiri ${ }^{26}$.

Tentang ketentuan dari akta otentik sebagai alat pembuktian terdapat pada hukum pembuktian (bewijsrecht)yang diatur dalam buku IV Kitab Undang-Undang Hukum Perdata, bahwa alat bukti tertulis khususnya akta otentikdan apa syaratsyaratnya melihat pada Pasal 1869 dan 1870 Kitab Undang-Undang Hukum Perdata.

Pasal 1869 Kitab Undang Undang

Hukum Perdatamenyatakan:

"Suatu akta yang karena tidak berkuasa atau tidakcakapnya pegawai dimaksud diatas atau karena suatu cacat dalam bentuknya tidak dapat diperlakukan sebagai akta otentik akan tetapi mempunyai kekuatan sebagai akta dibawah tangan jika akta itu ditandatangani para pihak".

Berdasarkan Pasal 1869 Kitab Undang UndangHukum Perdata diatas, ketika suatu akta otentik yang dibuat oleh pejabat umum yang tidak berwenang untuk itu maka akta tersebut tidak lagi mempunyai kekuatan pembuktian sebagai akta otentik yaitu kekuatan pembuktian sempurna melainkan hanya mempunyai kekuatan pembuktian dibawah tangan. Pejabat umum yang tidak berwenang dalam hal ini yaitu selain yang disebutkan

dalam

PMK
No.27/PMK.06/2016 Tentang Petunjuk Pelaksanaan Lelang, $\quad$ PMK No.158/PMK.06/2013 tentang Pejabat Lelang Kelas I, dan PMK No.159/PMK.06/2016tentang Pejabat Lelang Kelas II.Demikian pula jika terdapat cacat bentuk dari akta otentik itu, misalnya bentuknya menyimpang dengan yang telah ditentukan oleh undang-undang yang bersangkutan maka kekuatan pembuktian yang sempurna dari akta otentik itu menjadi turun derajatnya menjadi akta dibawah tangan. Aktaotentik itu memberikan kepada para pihak suatupembuktian yang mutlak mengenai peristiwa-peristiwa yang disebut dalam akta itu, dalam pembuktian bahwa apa yang tersebut dalam akta otentik itu pada pokoknya harus dianggap benar. Ketentuan tersebut bila dihubungkan dengan Staatblad 1908 No.189 atau Peraturan Lelang (Vendu Reglement) bisa dilihat dalam pasal-pasal yang mengatur mengenai Akta Risalah Lelang yaitu Pasal 37, 38, dan 39.

\section{Kesimpulan}

Berdasarkan pemaparan hasil penelitian danpembahasan pada bab sebelumnya, dapat ditarikkesimpulan untuk menjawab permasalah yang dalampenelitian ini, yaitu :

1. Kedudukan Akta Risalah Lelang disebut sebagai akta otentik atau otentisitas akta

${ }^{26}$ Ibid., hlm. 260 
karena memenuhi beberapa unsur : (1) bentuk akta otentik itu diatur undangundang. Risalah lelang bentuknya diatur dalam pasal 37, 38 dan $39 V e n d u$ Reglement; (2) akta otentik itu harus dibuat oleh atau dihadapan pejabat umum.Risalah lelang dibuat oleh pejabat lelang.Pejabat Lelang yang diangkat Direktur Jenderal yang dimaksud adalah Notaris.Kemudian dalam Pasal 35 Vendu Reglement dinyatakan bahwa setiap penjualan dimuka umum/ lelang harus dibuat berita acara lelang/risalah lelang. (3) tentang kewenangan apa, kapan, dan dimana akta itu dibuat. Untuk risalah lelang dapat kita lihat ketentuan Pasal 3 dan 7 Vendu Reglement bahwa kapan dan wilayah kerja pejabat lelang ditentukan oleh Menteri Keuangan.

2. Kekuatan Pembuktian Pada Akta Risalah Lelang Sebagai akta otentik, Dalam Pasal 35 Vendu Reglementdisebutkan bahwa "Dari tiap penjualan dimuka umum oleh Pejabat Lelang atau kuasanya, selama dalam penjualan, untuk tiap hari pelelangan atau penjualan dibuat berita acara tersendiri”. Disini jelas bahwa Risalah Lelang harus dibuat dengan akta otentik, untuk itu peranan Notaris sebagai pejabat pembuat akta sangat diperlukan, karena risalah lelang mempunyai kekuatan pembuktian yang sempurnah tentang apa yang dimuat di dalamnya. Artinya bahwa apa yang tersebut dalam akta otentik itu pada pokoknyaharus dianggap benar sebagaimana ketentuan dalam Pasal 37, 38, dan 39 (Vendu Reglement Staatblad 1908 No.189), Hal ini dikarenakan Pejabat Lelang dalam membuat akta otentik atau risalah lelang sesuai dengan apa yang dilihat dan didengar olehnya.

\section{Saran}

Berdasarkan pemaparan hasil penelitian danpembahasan pada bab sebelumnya, saran yang dapatdiberikan atas permasalahan dalam penelitian iniadalah :

1. Kewenangan Notaris dalam membuat akta Risalah lelang yang terdapat dalam Pasal 15 ayat (2) huruf g UUJN tidak dapat diterapkan begitu saja dikarenakan berdasarkan vendu reglement hanya pejabat lelang yang diangkat oleh Menteri Keuangan yang berhak membuat Akta Risalah Lelang, hal ini menimbulkan pertentangan dan ketidakpastian hukum baik di kalangan Notaris maupun masyarakat. Dan sebaiknya 
Pemerintah dan Dewan Perwakilan

Rakyat (DPR) untuk segera membuat Undang-Undang baru khususnya tentang Lelang dikarenakan Vendu Reglement Staadblad 1908 Nomor 189 dan Vendu Instructie Staadblad 1908 Nomor 190 sudah tidak sesuai dengan perkembangan saat ini meskipun sudah ada Peraturan Menteri Nomor 27/PMK. 06/2016 tentang Petunjuk Pelaksanaan Lelang.

2. Pemerintah diharapkan dapat meningkatkan pelayanan kepada penjual yang ingin menjual barangnya melalui lelang serta memberi kemudahan bagi pembeli yang ingin membeli barang melalui lelang. Dan diharapkan dengan adanya Notaris dalam pembuatan Risalah Lelang akan memberi kemudahan bagi pembeli dan penjual untuk membuat Risalah Lelang sebagai tanda bukti jual beli dalam lelang.

\section{Ucapan Terima Kasih}

Papa (alm) Drs. Kasim Lembah, mama Dra. Hj. Maryam Hasyim, Mertua tercinta H. Muchlas Bone, S.Sos, Hj. Nani Ladewa, Isteriku Median Lestari, SE, buat anak-anakku Najwa Ratu
Madika Lembah dan Najmah Aulia Madika Lembah serta semua Saudara dan keluarga atas semua doa, kasih sayang, dukungannya.

\section{DAFTAR PUSTAKA}

\section{Buku :}

Adjie, Habib, Hukum Notaris Indonesia, Refika Aditama, Bandung, 2009

Arie Purnomosidi \&Teguh Prasetyo, Membangun Hukum Berdasarkan Pancasila, Nusa Media, Bandung, 2014 Ekowati Pujining Rahayu, Notaris Sebagai

Pejabat Lelang Kelas II Dalam Pelaksanaannya, (Semarang : Tesis Program Pasca Sarjana Magister Kenotariatan Univesitas Diponegoro, 2007)

F. X. Ngadijarno (Dkk),Op.Cit., Irawan Soeradjo, Kepastian Hukum Hak Atas Tanah Di Indonesia, Arkola, Surabaya, 2003

Kraan C.A., De Authentieke Akte, Gouda Quint BV, Arnhem 1984

Marzuki Peter Mahmud, Penelitian Hukum, Kencana Prenada Media Group, Jakarta, 2005 
M. Yahya Harahap. 1994. Ruang Lingkup Permasalahan Eksekusi Bidang Perdata. Jakarta: Gramedia,

Muchlis Fatahna, Joko Purwanto,Notaris Bicara Soal Kenegaraan, Jakarta: Watampone Press, 2003

R. Soegando Notodisoerjono, Hukum Notariat di Indonesia Suatu Penjelasan, Raja Grafindo Persada, Jakarta, 1993

Peter Mahmud Marzuki, Penelitian Hukum,

Kencana Prenada Media Group,Jakarta, 2005

Peter Mahmud Marzuki,Penelitian Hukum,

Kencana Prenada Media, Jakarta, 2010

Salim HS, Hukum Kontrak-Teori dan Teknik

Penyusunan Kontrak, Sinar Grafika,

Jakarta, 2006

Syaifurrachman dan Habib Adjie.2011.

Aspek Pertanggungjawaban Notaris dalam Pembuatan Akta.Surabaya : Mandar Maju

\section{A. Peraturan Perundang-Undangan}

Undang-Undang Nomor 30 Tahun 2004

Tentang Jabatan Notaris;

Undang-Undang Republik Indonesia Nomor

2 Tahun 2014 Tentang Perubahan Atas Undang-Undang Nomor 30 Tahun 2004 Tentang Jabatan Notaris;

Peraturan Lelang (Vendu Reglement)

Ordonantie Staatblaad 1908:189;
Intruksi Lelang (Vendu Intructie) Staatblaad 1908:190;

Peraturan Menteri Keuangan Nomor 175/PMK.06/2010 tentang Pejabat Lelang Kelas II (Berita Negara Republik Indonesia Tahun 2010 Nomor 475) sebagaimana telah diubah dengan Peraturan Menteri Keuangan Nomor 159/PMK.06/2013 tentang Perubahan atas Peraturan Menteri Menteri Keuangan Nomor 175/PMK.06/2010 tentang Pejabat Lelang Kelas II (Berita Negara Republik Indonesia Tahun 2013 Nomor 1338) dalam melaksanakan Lelang Kelas II.

Peraturan Menteri Keuangan Nomor: 27/PMK. 06/2016 tentang Petunjuk Pelaksana Lelang

\section{B. Jurnal, Tesis, Disertasi dan Karya Ilmiah}

M. Hadjon Phillipus, “Tentang Wewenang”, Makalah Universitas Airlangga, Surabaya Tentang Wewenang, Yuridika, No 5 \& 6 Tahun XII, September - Desember, 1997

Hukum Administrasi dan Good Governance, Cet. II., Universitas Trisakti, Jakarta, 2012

Departemen Keuangan Republik Indonesia Direktorat Jenderal Piutang dan Lelang Negara, 2005, Naskah Akademik 
Rancangan Undang-Undang Lelang,

Jakarta: Biro Hukum Sekretariat Jenderal.

Nurul Muslimah Kurniati, Notaris Dan Akta

Notaris, tedapat dalam

http://notarisnurulmuslimahkurniati.blogs

pot.co.id/2009/04/notaris-dan-akta-

notaris.html 